\title{
Floristic Diversity and Distribution Pattern of Plant Communities along Altitudinal Gradient in Sangla Valley, Northwest Himalaya
}

\author{
Pankaj Sharma, ${ }^{1}$ J. C. Rana, ${ }^{1}$ Usha Devi, ${ }^{1}$ S. S. Randhawa, ${ }^{2}$ and Rajesh Kumar ${ }^{3}$ \\ ${ }^{1}$ National Bureau of Plant Genetic Resources, Regional Station, Phagli, Shimla 171 004, India \\ ${ }^{2}$ State Council for Science, Technology and Environment, Shimla 171 009, India \\ ${ }^{3}$ School of Basic Sciences and Research, Sharda University, Knowledge Park III, Greater Noida, Gautam Budh Nagar 201306, India \\ Correspondence should be addressed to J. C. Rana; ranajc2003@yahoo.com
}

Received 30 June 2014; Revised 22 August 2014; Accepted 22 August 2014; Published 14 October 2014

Academic Editor: Shixiong Cao

Copyright (C) 2014 Pankaj Sharma et al. This is an open access article distributed under the Creative Commons Attribution License, which permits unrestricted use, distribution, and reproduction in any medium, provided the original work is properly cited.

\begin{abstract}
Himalayas are globally important biodiversity hotspots and are facing rapid loss in floristic diversity and changing pattern of vegetation due to various biotic and abiotic factors. This has necessitated the qualitative and quantitative assessment of vegetation here. The present study was conducted in Sangla Valley of northwest Himalaya aiming to assess the structure of vegetation and its trend in the valley along the altitudinal gradient. In the forest and alpine zones of the valley, 15 communities were recorded. Study revealed 320 species belonging to 199 genera and 75 families. Asteraceae, Rosaceae, Apiaceae, and Ranunculaceae were dominant. Among genera, Artemisia followed by Polygonum, Saussurea, Berberis, and Thalictrum were dominant. Tree and shrub's density ranged from 205 to 600 and from 105 to 1030 individual per hectare, respectively, whereas herbs ranged from 22.08 to 78.95 individual $/ \mathrm{m}^{2}$. Nearly 182 species were native to the Himalaya. Maximum altitudinal distribution of few selected climate sensitive species was found to be highest in northeast and north aspects. This study gives an insight into the floristic diversity and community structure of the fragile Sangla Valley which was hitherto not available.
\end{abstract}

\section{Introduction}

Himalayas comprised of earth's most multifaceted and diverse montane ecosystems, characterized by a harsh climate, a strong degree of seasonality, and a high diversity of both plant communities and species $[1,2]$. These are geodynamic young mountains and have been recognized as one of the globally important biodiversity hotspots $[3,4]$. In these mountains presence of often sharp environmental gradients due to rapid geoclimatic variations generate diverse vegetation and community types having high plant species diversity [5]. Here a wide range of altitude, rainfall, climate, geological conditions, river systems, and topography have given rise to an immense diversity of ecosystems and ultimately to immense biological diversity.

The structure, composition, and vegetative functions are most significant ecological attributes of a particular ecosystem, which show variations in response to environmental as well as anthropogenic variables [6-8]. Major threats to ecosystems and biodiversity are habitat loss and fragmentation, overexploitation, pollution, invasions of alien species, and global climate change [9] with disruption of community structure.

The vegetation distribution pattern, communities, and population dynamics in high altitude arid areas of the fragile Himalaya have seldom given the due attention by researchers and are hence poorly understood. Furthermore, altitude and aspect are the major topographic factors that control the distribution patterns of vegetation in mountain areas. These factors determine the microclimate and thus the distribution of vegetation in the mountain areas [10]. The anthropogenic pressures, heavy grazing, and the natural calamities have led to degradation of natural habitats of many species. Such practices are discouraging the moisture loving native species and promoting the hardy nonnative exotic species having little value for the local ecosystem [11]. 
The rapid loss in floristic diversity and changing pattern of vegetation due to various biotic and abiotic factors have necessitated the qualitative and quantitative assessment of vegetation. However numbers of studies on community dynamics and phytogeographic affinities have been conducted qualitatively [12-17] as well as quantitatively [5, 1824] and in northwest Himalaya [4, 6, 25-27] in particular as well. Nevertheless, a very few studies incorporating composition, structural and functional diversity, and nativity of the biodiversity have been carried out in northwest Himalaya [28-31]. But not many studies that give detailed account of floristic diversity of Kinnaur [5], which forms a typical geographical entity of Himachal Pradesh and Sangla Valley in particular, are available till now. Therefore, this work is emphasized to study floristic composition; to assess the community structure of the vegetation by different phytosociological methods and phytogeographic affinities of the species; and to study the vegetation pattern in the different aspects of the SV along an altitudinal gradient.

\section{Materials and Methods}

2.1. Physiographic Features of the Study Area. The study area is commonly known as Sangla Valley (hereafter, SV) and situated at $31^{\circ} 31^{\prime}-36^{\prime} \mathrm{N}$ and $77^{\circ} 20^{\prime}-27^{\prime} \mathrm{E}$ along the Baspa River that flows through the middle of valley (Figure 1). The valley is oriented from southeast to northwest directions. This is one of the most ecologically fragile biogeographical zones [32] and inhabited by indigenous tribal communities having Mongolian features and Buddhist religion and culture. It is surrounded by high mountains with elevation ranging from 1800 to $5480 \mathrm{~m}$ above mean sea level. The upper ranges of the valley are highly glaciered and receive most of its water through dry precipitation (snow) in winters from November to April. The vegetation of the valley is temperate; subalpine and alpine types and forests are dominated by Pinus wallichiana, Betula utilis, Abies pindrow, and Cedrus deodara communities. The livelihood of communities is based on agrihorticultural activities, which are generally performed after snow melt in April to October. The communities have close affinity with plant resources not only to meet their basic requirements like food, fodder, fuel, health, and shelter but also to perform several religious and cultural rituals. Though the environment of the valley is very close to nature, several anthropogenic activities have successfully altered the natural and traditional agroecosystem of the valley. Several new climatic events such as increasing frequency of rains in July-August (150-200 mm in 1980s to $465 \mathrm{~mm}$ in 2012), rising temperature, frost, and fog are being witnessed more frequently than two decades ago.

2.2. Sampling Plot and Estimation Design. Representative plots of $50 \times 50 \mathrm{~m}$ were selected in different aspects and habitats. 10 quadrats of $10 \times 10 \mathrm{~m}$ for trees, 20 quadrats of 5 $\times 5 \mathrm{~m}$ for shrubs, and 20 quadrats of $1 \times 1 \mathrm{~m}$ for herbs were randomly laid within the plot. Plots were selected based on different topographical features such as habitat types, altitude, aspects, slope, and different vegetation types (Table 1). The habitats were identified based on the physical characters and dominance of the vegetation. The plots facing high anthropogenic pressure were considered as degraded habitats and sites having closed canopy with high percent of humus and moisture were considered as moist habitat whereas those of low percent of the same were considered as dry habitat. The site having $>50 \%$ boulders of the ground cover were considered as bouldery habitat. Geographical coordinates of the sites were taken with the help of Global Positioning System (GPS). Slope was measured with the help of Abney's level.

Sites were selected in each and every aspect between 1950 and $4500 \mathrm{~m}$ for the field study and analysis of floristic diversity. In various representative ecoclimatic zones of SV, 34 plots were sampled.

2.3. Data Analysis. The SV, which falls under cold arid zone of Himachal Pradesh, is diverse and rich in species. Communities were identified based on the importance value index and calculated as the sum of relative frequency, relative density, and relative basal area/relative abundance. For diversity index, Shannon-Wiener information index [33] was used. Species richness was considered as the total number of species in a growth form. For the collection and analysis of data standard ecological methods [20, 24, 34-39] were followed. Vegetation was analytically computed following $[39,40]$. The taxa of Himalayan origin were considered as native and all others as nonnative. During qualitative assessment, rapid surveys and samplings were done in each season and taxa identified on spot and with the help of floras and research papers [12-14, 40-43].

\section{Results and Discussion}

Plots accessed were 34 in number and a total 15 communities (9 tree, 5 shrub, and 1 herb communities) were delineated based on importance value index for the tree communities and relative density for the shrub and herb communities.

3.1. Vegetational Analysis. The different habitats covered during the study were shady moist, rocky, bouldery, dry, alpine meadow, riverine, moraines, and so forth. Among these, shady moist (12) followed by dry habitats (9) represented maximum sites. Because of unique topography and different altitudinal zones of western Himalaya, vegetation varies from aspect to aspect. The sites were selected in every accessible habitat and aspect along an altitudinal gradient. North and northeastern aspects represented maximum sites (8 each) followed by southwest and northwest (5 each) (Table 1 ).

Within the communities so delineated, we recorded 320 species of plants belonging to 199 genera and 75 families. Dominant group reported was angiosperms, (68 families, 190 genera, and 302 species); gymnosperms represented by 4 families, 7 genera, and 13 species and pteridophytes by 4 families, 3 genera, and 5 species. They were distributed in different life forms, that is, trees (29 spp.), shrubs (43 spp.), and herbs (248 spp.) (Table 2). 


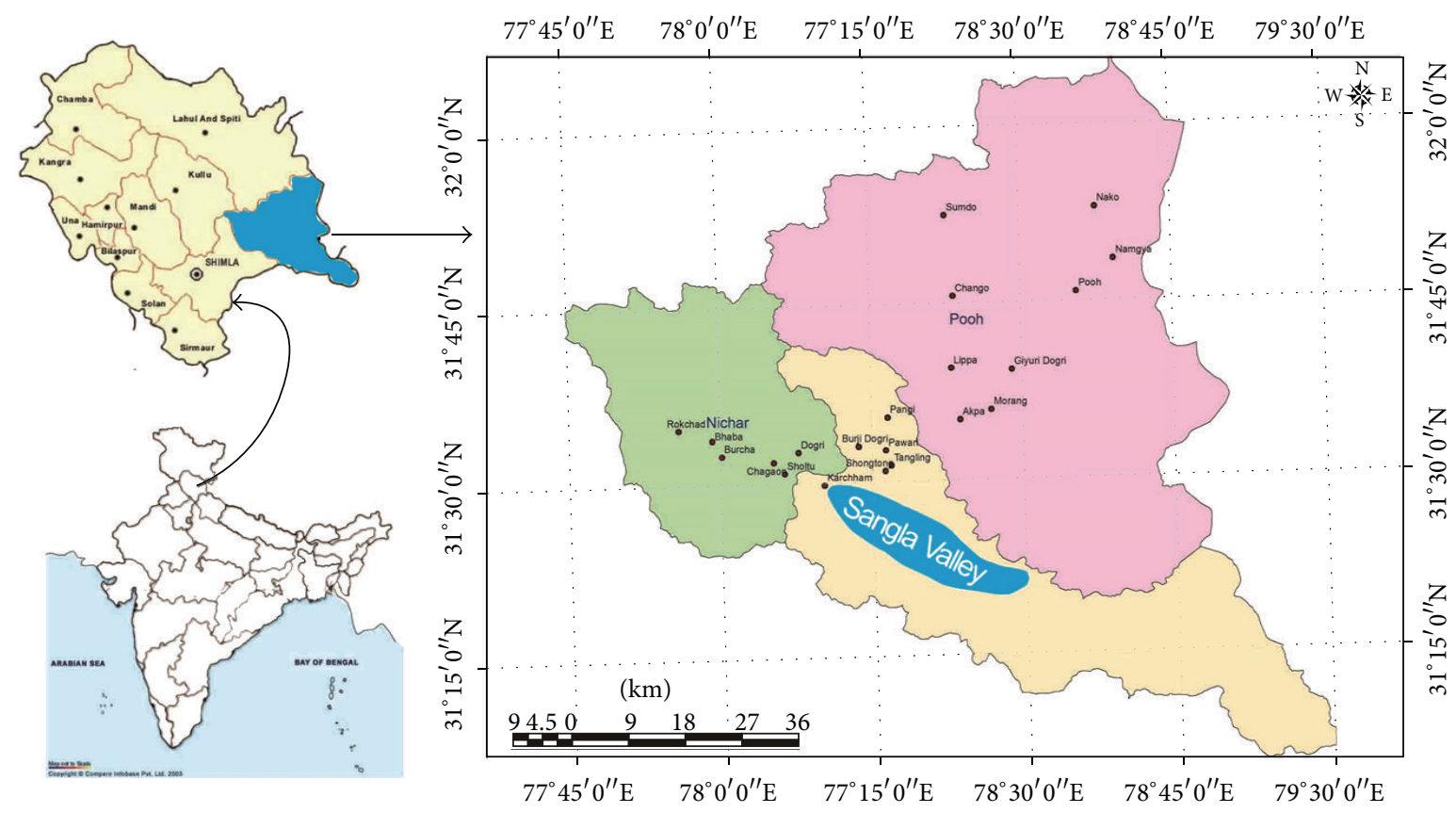

Figure 1: Map of the study area.

Among the angiosperm families, Asteraceae (49 spp.); Rosaceae (21 spp.); Apiaceae (20 spp.); and Ranunculaceae (18 spp.) were dominant. Among genera, Artemisia and Polygonum (7 spp.); Saussurea (6 spp.); Berberis and Thalictrum (5 spp.), and Geranium, Juniperus, Nepeta, Potentilla, Poa, Rosa, and Salix (4 spp. each) were dominant genera. Twentyeight (28) families were monotypic and represented only by one species. The occurrence of 320 species in the quantified area indicates that its environmental conditions, particularly shady moist and forest habitats, are suitable for the growth and development of species. Amongst the communities, $P$. wallichiana community represented maximum sites (6 sites), followed by $B$. utilis (5 sites); B. utilis-P. wallichiana mixed (4 sites); C. deodara and P. gerardiana (3 sites, each); $R$. anthopogon, $H$. salicifolia, and $R$. anthopogon-S. caliculata mixed ( 2 sites, each), and the rest of the communities were represented by one site only. Dominance of the Asteraceae in SV is also validated by floras of Lahaul-Spiti, Himachal Pradesh, in high altitude regions of western Himalaya $[13,42]$. The affinity of vegetation towards the flora of the Lahaul-Spiti Valley and Bhaba Valley $[5,42]$ is apparent by the presence of similar dominant families. Moreover, the major part of the valley is covered with snow throughout the year. Presence of number of herbaceous families (namely, Apiaceae, Brassicaceae, Ranunculaceae, Rosaceae, Polygonaceae, and Scrophulariaceae) is attributed to the temperate and alpine nature of the area. Lesser Pteridophytes in the area may be attributed to the more exposed arid nature of the valley with low broad leaf forest cover and moisture. Nonetheless, as a whole, the high diversity and richness of the species in the SV indicate the high conservation value of the area. Occurrences of 320 species in the 15 identified communities of 34 quantified plots validate this.
3.2. Communities: Composition and Structure. Total tree density ranged from 205 to 600 no./ha (number per hectare) and total basal area from 8.70 to $42.41 \mathrm{~m}^{2} /$ ha. Shrubs and herbs densities ranged from 105.0 to 1030.00 no./ha and from 22.08 to 48.73 no. $/ \mathrm{m}^{2}$ respectively. Shrub density is maximum in $C$. deodara-P. smithiana mixed community and herbs density is maximum in Poa alpina-Agrostis stolonifera-Bistorta affinisAconitum violaceum community. Among five major shrub communities, Spiraea canescens-Lonicera hypoleuca mixed community has highest shrub and herb density, that is, 540.00 no./ha and 48.73 no. $/ \mathrm{m}^{2}$, respectively (Table 3 ). Tree density range is comparable to the other Himalayan studies $[40,44]$ and European temperate forests [45]. Similarly, shrub and herb's density ranges (105-1030 no./ha and 22.08$78.95 \mathrm{no} . / \mathrm{m}^{2}$, resp.) are in compliance with the earlier studies of the Himalayan regions [46]. However the lower range of shrub densities in $R$. anthopogon communities (105 no./ha and $230 \mathrm{no} . / \mathrm{ha}$ ) in the valley is due to the presence of its scanty patches near the subalpine areas and often the rugged and arid and moraine topography.

3.3. Species Richness and Diversity Index $\left(H^{\prime}\right)$. Species richness in identified communities ranged from 19 to 96. Among the communities, it was highest in $P$. wallichiana (96 spp.), followed by B. utilis-P. wallichiana mixed (80 spp.), R. anthopogon-S. caliculata mixed (52 spp.), and $P$. gerardiana (47 spp.) communities. Species diversity index for trees is maximum (1.28) for C. deodara-P. smithiana mixed community and minimum (0.0) for Q. floribunda and $P$. wallichiana communities; among shrubs it is maximum (2.38) for P. wallichiana community and minimum (0.40) for Q. floribunda community and for herbs it is maximum (4.01) 
TABle 1: Physical Characteristics of the plots assessed in Sangla Valley.

\begin{tabular}{|c|c|c|c|c|c|c|}
\hline S. No. & Altitude (m) & Habitat & Slope & Aspect & Latitude & Longitude \\
\hline 1 & 1950 & Degraded & $35^{\circ}$ & $\mathrm{S}$ & $31^{\circ} 28.040 \mathrm{~N}$ & $78^{\circ} 11.209 \mathrm{E}$ \\
\hline 2 & 2000 & Dry & $60^{\circ}$ & NW & $31^{\circ} 28.853 \mathrm{~N}$ & $78^{\circ} 10.892 \mathrm{E}$ \\
\hline 3 & 2100 & Dry & $60^{\circ}$ & SW & $31^{\circ} 28.823 \mathrm{~N}$ & $78^{\circ} 10.962 \mathrm{E}$ \\
\hline 4 & 2250 & Dry & $50^{\circ}$ & S & $31^{\circ} 28.045 \mathrm{~N}$ & $78^{\circ} 11.111 \mathrm{E}$ \\
\hline 5 & 2550 & Shady Moist & $20^{\circ}$ & $\mathrm{N}$ & $31^{\circ} 25.025 \mathrm{~N}$ & $78^{\circ} 16.103 \mathrm{E}$ \\
\hline 6 & 2625 & Riverine & $50^{\circ}$ & $\mathrm{NE}$ & $31^{\circ} 24.854 \mathrm{~N}$ & $78^{\circ} 16.828 \mathrm{E}$ \\
\hline 7 & 2675 & Bouldery & $40^{\circ}$ & $\mathrm{N}$ & $31^{\circ} 25.061 \mathrm{~N}$ & $78^{\circ} 16.368 \mathrm{E}$ \\
\hline 8 & 2690 & Dry & $15^{\circ}$ & $\mathrm{NE}$ & $31^{\circ} 24.913 \mathrm{~N}$ & $78^{\circ} 16.085 \mathrm{E}$ \\
\hline 9 & 2750 & Shady Moist & $10^{\circ}$ & SW & $31^{\circ} 25.758 \mathrm{~N}$ & $78^{\circ} 16.746 \mathrm{E}$ \\
\hline 10 & 2770 & Shady Moist & $45^{\circ}$ & $\mathrm{NE}$ & $31^{\circ} 24.342 \mathrm{~N}$ & $78^{\circ} 18.038 \mathrm{E}$ \\
\hline 11 & 3120 & Bouldery & $20^{\circ}$ & $\mathrm{NE}$ & $31^{\circ} 23.039 \mathrm{~N}$ & $78^{\circ} 21.614 \mathrm{E}$ \\
\hline 12 & 3185 & Dry & $30^{\circ}$ & SW & $31^{\circ} 23.631 \mathrm{~N}$ & $78^{\circ} 21.370 \mathrm{E}$ \\
\hline 13 & 3250 & Dry & $45^{\circ}$ & S & $31^{\circ} 24.342 \mathrm{~N}$ & $78^{\circ} 18.038 \mathrm{E}$ \\
\hline 14 & 3320 & Dry & $35^{\circ}$ & SW & $31^{\circ} 21.286 \mathrm{~N}$ & $78^{\circ} 24.438 \mathrm{E}$ \\
\hline 15 & 3340 & Shady Moist & $55^{\circ}$ & SW & $31^{\circ} 23.840 \mathrm{~N}$ & $78^{\circ} 21.340 \mathrm{E}$ \\
\hline 16 & 3350 & Rocky & $60^{\circ}$ & S & $31^{\circ} 21.756 \mathrm{~N}$ & $78^{\circ} 24.029 \mathrm{E}$ \\
\hline 17 & 3385 & Dry & $45^{\circ}$ & $\mathrm{N}$ & $31^{\circ} 20.992 \mathrm{~N}$ & $78^{\circ} 26.287 \mathrm{E}$ \\
\hline 18 & 3399 & Dry & $40^{\circ}$ & $\mathrm{N}$ & $31^{\circ} 23.640 \mathrm{~N}$ & $78^{\circ} 21.558 \mathrm{E}$ \\
\hline 19 & 3400 & Shady Moist & $40^{\circ}$ & $\mathrm{N}$ & $31^{\circ} 20.955 \mathrm{~N}$ & $78^{\circ} 26.135 \mathrm{E}$ \\
\hline 20 & 3420 & Shady Moist & $40^{\circ}$ & NW & $31^{\circ} 23.209 \mathrm{~N}$ & $78^{\circ} 25.577 \mathrm{E}$ \\
\hline 21 & 3450 & Bouldery & $50^{\circ}$ & $\mathrm{W}$ & $31^{\circ} 23.881 \mathrm{~N}$ & $78^{\circ} 21.441 \mathrm{E}$ \\
\hline 22 & 3480 & Shady Moist & $50^{\circ}$ & NW & $31^{\circ} 20.886 \mathrm{~N}$ & $78^{\circ} 26.179 \mathrm{E}$ \\
\hline 23 & 3500 & Shady Moist & $40^{\circ}$ & NW & $31^{\circ} 23.959 \mathrm{~N}$ & $78^{\circ} 21.554 \mathrm{E}$ \\
\hline 24 & 3501 & Moraine & $45^{\circ}$ & SE & $31^{\circ} 20.967 \mathrm{~N}$ & $78^{\circ} 27.303 \mathrm{E}$ \\
\hline 25 & 3516 & Rocky & $40^{\circ}$ & SE & $31^{\circ} 21.002 \mathrm{~N}$ & $78^{\circ} 27.381 \mathrm{E}$ \\
\hline 26 & 3527 & Moraine & $45^{\circ}$ & SE & $31^{\circ} 21.002 \mathrm{~N}$ & $78^{\circ} 27.374 \mathrm{E}$ \\
\hline 27 & 3650 & Shady Moist & $40^{\circ}$ & $\mathrm{N}$ & $31^{\circ} 20.636 \mathrm{~N}$ & $78^{\circ} 26.224 \mathrm{E}$ \\
\hline 28 & 3700 & Shady Moist & $40^{\circ}$ & $\mathrm{N}$ & $31^{\circ} 20.515 \mathrm{~N}$ & $78^{\circ} 26.267 \mathrm{E}$ \\
\hline 29 & 3770 & Shady Moist & $35^{\circ}$ & NW & $31^{\circ} 20.389 \mathrm{~N}$ & $78^{\circ} 26.334 \mathrm{E}$ \\
\hline 30 & 3850 & Shady Moist & $30^{\circ}$ & $\mathrm{NE}$ & $31^{\circ} 20.167 \mathrm{~N}$ & $78^{\circ} 26.411 \mathrm{E}$ \\
\hline 31 & 4129 & Alpine meadow & $45^{\circ}$ & $\mathrm{NE}$ & $31^{\circ} 19.310 \mathrm{~N}$ & $78^{\circ} 26.151 \mathrm{E}$ \\
\hline 32 & 4205 & Alpine meadow & $25^{\circ}$ & $\mathrm{N}$ & $31^{\circ} 19.242 \mathrm{~N}$ & $78^{\circ} 26.049 \mathrm{E}$ \\
\hline 33 & 4330 & Moraine & $30^{\circ}$ & $\mathrm{NE}$ & $31^{\circ} 18.831 \mathrm{~N}$ & $78^{\circ} 25.888 \mathrm{E}$ \\
\hline 34 & 4500 & Alpine meadow & $20^{\circ}$ & $\mathrm{NE}$ & $31^{\circ} 18.347 \mathrm{~N}$ & $78^{\circ} 25.648 \mathrm{E}$ \\
\hline
\end{tabular}

TABLE 2: Taxonomic account of floristic diversity.

\begin{tabular}{|c|c|c|c|c|c|c|}
\hline Taxonomic group & Families & Genera & Species & Herbs & Shrubs & Trees \\
\hline Angiosperms & 68 & 190 & 302 & 243 & 39 & 20 \\
\hline Gymnosperms & 4 & 7 & 13 & - & 4 & 9 \\
\hline Pteridophytes & 3 & 3 & 5 & 5 & - & - \\
\hline Total & 75 & 200 & 320 & 248 & 43 & 29 \\
\hline
\end{tabular}

for P. wallichiana community and minimum (2.49) for $Q$. floribunda community (Table 3 ).

The species richness (19-96) in the communities was higher than the earlier reported values $[47,48]$ but comparable to the $[24,49]$ from high altitude areas of Himalaya. The high richness of trees and shrubs may be due to diverse habitats and suitable edaphic and climatic factors supporting growth and survival of the species. The diversity index for trees $(0.0-1.28)$ is within the reported value from the other Himalayan areas $[40,47,49,50]$. In $P$. gerardiana community, it is the only tree species which is present, so its diversity index value is zero. The diversity of shrubs $(0.40-$ 2.38) is comparable to the previous records from the higher Himalaya and also from the lower parts (0.51-1.33) [46, 48, 
TABle 3: Identified communities showing TBA, species richness, densities, and diversity in Sangla Valley.

\begin{tabular}{|c|c|c|c|c|c|c|c|c|c|}
\hline \multirow{2}{*}{ Communities } & \multirow{2}{*}{ SR } & \multirow{2}{*}{ TBA $\left(\mathrm{m}^{2} / \mathrm{ha}\right)$} & \multirow{2}{*}{ Species richness } & \multicolumn{3}{|c|}{ Density } & \multicolumn{3}{|c|}{ Species diversity index $\left(H^{\prime}\right)$} \\
\hline & & & & Trees (no./ha) & Shrubs (no./ha) & Herbs $\left(\right.$ no. $\left./ \mathrm{m}^{2}\right)$ & Trees & Shrubs & Herbs \\
\hline \multicolumn{10}{|l|}{ Trees } \\
\hline $\mathrm{BU}$ & 5 & 11.17 & 47 & 480 & 330 & 35.16 & 0.73 & 2.12 & 3.17 \\
\hline $\mathrm{CD}$ & 3 & 42.41 & 38 & 403.33 & 673.33 & 33.44 & 0.57 & 1.68 & 3.62 \\
\hline QF & 1 & 14.17 & 19 & 340 & 290 & 22.08 & 0 & 0.4 & 2.49 \\
\hline PG & 3 & 12.09 & 47 & 490 & 606.29 & 35.20 & 0.82 & 1.16 & 3.11 \\
\hline PW & 6 & 8.702 & 96 & 205 & 625.83 & 36.34 & 0 & 2.38 & 4.01 \\
\hline BU-AP & 1 & 14.16 & 35 & 440 & 770 & 25.03 & 1.02 & 1.52 & 3.16 \\
\hline BU-PW & 4 & 12.28 & 80 & 420 & 327.5 & 40.36 & 0.93 & 2.22 & 3.69 \\
\hline CD-PS & 1 & 17.98 & 41 & 600 & 1030 & 42.40 & 1.28 & 2.07 & 2.98 \\
\hline CD-PW & 1 & 21.99 & 29 & 400 & 420 & 38.20 & 0.69 & 0.95 & 3.07 \\
\hline \multicolumn{10}{|l|}{ Shrubs } \\
\hline HS & 2 & - & 41 & - & 370 & 45.39 & - & 1.63 & 3.21 \\
\hline RA & 2 & - & 40 & - & 105 & 32.56 & - & 0.96 & 3.45 \\
\hline RA-SC & 2 & - & 52 & - & 230 & 34.80 & - & 1.15 & 3.55 \\
\hline SCa-CB-BJ & 1 & - & 34 & - & 540 & 48.73 & - & 1.53 & 2.87 \\
\hline SCa-LH & 1 & - & 33 & - & 630 & 27.70 & - & 1.43 & 3.1 \\
\hline \multicolumn{10}{|l|}{ Herbs } \\
\hline PA-AS-BA-AV & 1 & - & 34 & - & - & 78.95 & - & - & 2.91 \\
\hline
\end{tabular}

$\mathrm{SR}=$ site represented, $\mathrm{TBA}$ : total basal area, $\mathrm{Ind}=$ individual, $\mathrm{BU}=$ Betula utilis, $\mathrm{CD}=$ Cedrus deodara, $\mathrm{QF}=$ Quercus floribunda, $\mathrm{PG}=$ Pinus gerardiana, $\mathrm{PW}$ = Pinus wallichiana, $\mathrm{BU}-\mathrm{AP}=$ Betula utilis-Abies pindrow mixed, $\mathrm{BU}-\mathrm{PW}=$ Betula utilis-Pinus wallichiana mixed, $\mathrm{CD}-\mathrm{PS}=$ Cedrus deodara-Picea smithiana, $\mathrm{CD}-\mathrm{PW}=$ Cedrus deodara-Pinus wallichiana mixed, $\mathrm{HS}=$ Hippophae salicifolia, $\mathrm{RA}=$ Rhododendron anthopogon, $\mathrm{RA}-\mathrm{SC}=$ Rhododendron anthopogon-Salix caliculata mixed, SCa-CB-BL = Spiraea canescens-Cotoneaster bacillaris-Berberis jaeschkeana mixed, SCa-LH = Spiraea canescens-Lonicera hypoleuca mixed, and PA-AS-BA-AV = Poa alpina-Agrostis stolonifera-Bistorta affinis-Aconitum violaceum.

$50]$ and $(0.74-3.14)$ reported by $[40,51]$ for subtropical and temperate forests. However for herbs diversity (2.49-4.01) it was higher than earlier records. The value of the total basal area was found to be maximum in C. deodara and C. deodaraP. wallichiana mixed communities $\left(42.41\right.$ and $21.99 \mathrm{~m}^{2} / \mathrm{ha}$, resp.) and average basal area is $17.23 \mathrm{~m}^{2} /$ ha which is very low as compared to the other parts of the Himalaya where it is above $70 \mathrm{~m}^{2} /$ ha [52-54]. This may be due to unscrupulous tree felling and logging pressure on the forest resources in addition to the other natural causes like heavy erratic rainfalls which leads to the massive landslides in the region.

3.4. Species Dominance in the Identified Communities. Among the various communities identified in SV, we figured out the maximum values of dominant species as $74.5 \%$ ( $B$. utilis) and $19.9 \%$ (P. wallichiana) in B. utilis community; $80.2 \%$ (C. deodara) and $17.4 \%$ (P. wallichiana) in C. deodara community; $100 \%$ (Q. floribunda) in Q. floribunda community as it was the only tree species present in the community; $57.14 \%$ (Pinus gerardiana) and $38.8 \%$ (Quercus floribunda) in Pinus gerardiana community; $90.9 \%$ (P. wallichiana) and $8.1 \%$ (C. deodara) in P. wallichiana community; $43.1 \%$ (B. utilis) and $40.9 \%$ (A. pindrow) in B. utilis-A. pindrow mixed community; $62.5 \%$ (B. utilis) and $29.8 \%$ (P. wallichiana) in $B$. utilis-P. wallichiana mixed community; $38.3 \%$ (C. deodara) and $31.6 \%$ (Picea smithiana) in C. deodara-P. smithiana mixed community; and 52.5\% (C. deodara) and $42.5 \%$
(P. wallichiana) in C. deodara-P. wallichiana mixed community (Table 4).

Among shrubs maximum density percentages were of the species Berberis aristata, Berberis jaeschkeana, Cassiope fastigiata, Cotoneaster bacillaris, Cotoneaster microphyllus, Desmodium elegans, Hippophae salicifolia, Lonicera hypoleuca, Rhododendron campanulatum, Rabdosia rugosa, Rhododendron anthopogon, Rubus ellipticus, Salix calyculata, Sorbaria tomentosa, Spiraea canescens, and so forth. Rabdosia rugosa $(80.1 \%)$ and Cotoneaster bacillaris (7.5\%) were having maximum and minimum density percentages in Quercus floribunda and Cedrus deodara communities, respectively. Among herbs assessed Aconogonum molle, Agrostis stolonifera, Bistorta affinis, Bromus japonicas, Cannabis sativa, Conyza sumatrensis, Cynoglossum wallichii, Delphinium cashmerianum, Euphrasia officinalis, Fragaria nubicola, Impatiens thomsonii, Morina longifolia, Nepeta erecta, Origanum vulgare, Persicaria vivipara, Poa alpina, Polygonatum verticillatum, Thalictrum cultratum, Trifolium pratense, and so forth were in abundance, hence showing comparatively more densities. Herbs having maximum density recorded were Poa alpina (25.3\%) followed by Cynoglossum wallichii (23.4\%) and Fragaria nubicola (19.5\%) in Poa alpina-Agrostis stolonifera-Bistorta affinis-Aconitum violaceum mixed, $B$. utilis-A. pindrow mixed, and Rhododendron anthopogon-Salix calyculata mixed communities, respectively (Table 4).

Tree, shrub, and herb percentage covers within the communities showed a typical composition of the Himalayan 


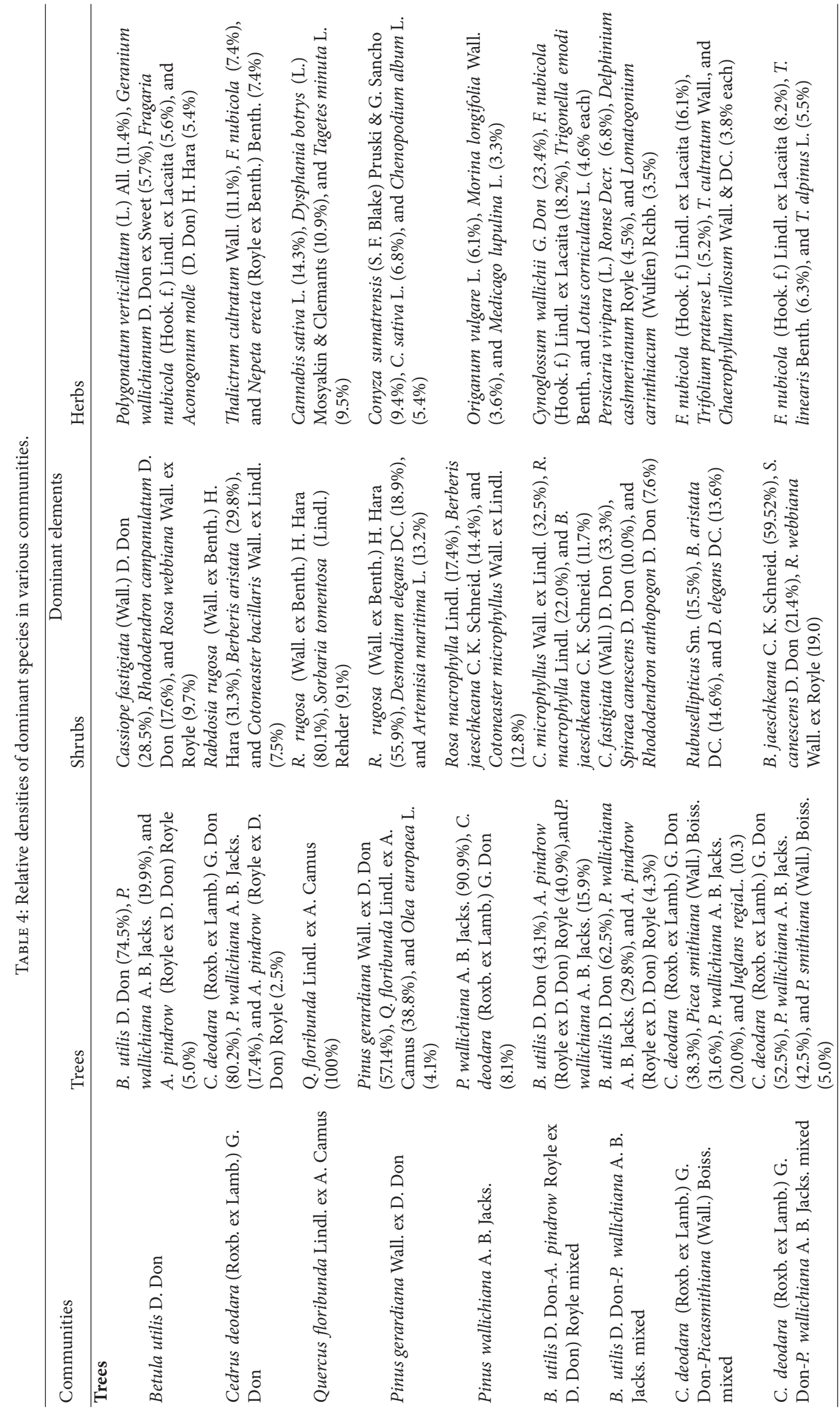




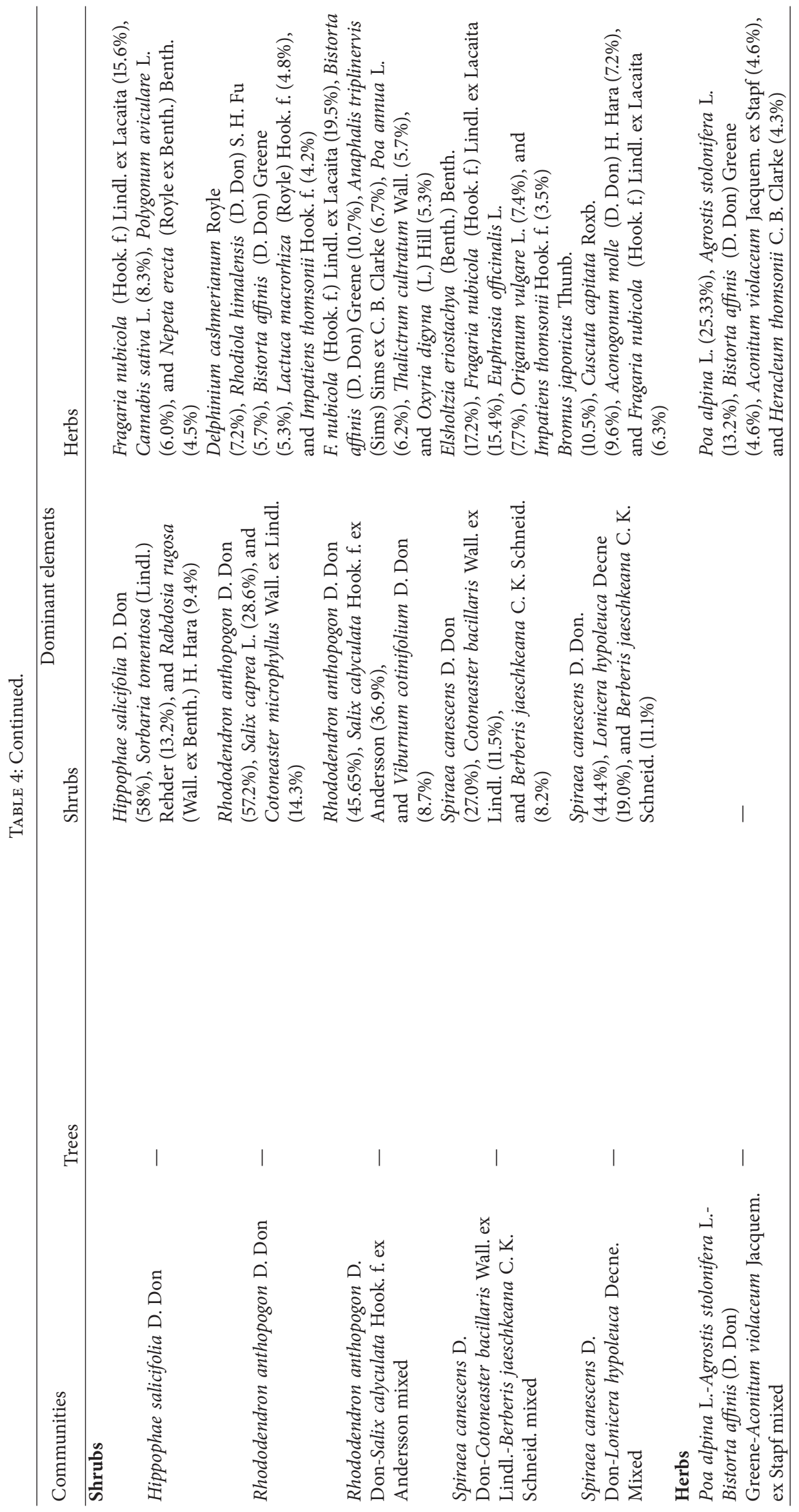


region wherein shrubs Rabdosia rugosa and Cotoneaster bacillaris were having maximum and minimum density percentages, respectively, and herbs Poa alpina, Cynoglossum wallichii,and Fragaria nubicola were abundant. Dominance of these species might be due to their high adaptability in addition to their good capability to proliferate in the extreme climatic conditions of this part of western Himalaya.

3.5. Phytogeographic Affinities. As a whole in all the communities, 182 species were native to the Himalayan region and the remaining were nonnatives as they are from different biogeographic domains of the world. The trend of nativity of plants occurring in SV was as follows: European/Oriental region (28) > Asia (25) > European region (16) > Temperate region (13) > Indian region (10) > India/Oriental region (8) $>$ America (7) $>$ European/Oriental/African and Temperate, Arctic (6 each) > Cosmopolitan (5) > Australian (4) > Amphigean (3) > Arctic, European/Oriental/American and Oriental (2 each) and European/African (1) (Figure 2).

Natives are the species which evolved naturally in a particular region before their human introduction. To prioritize a species or habitat of the region for conservation, status of a species as to whether it is native or introduced in a given area is required. Species invasions beyond their native range constitute a global driver of change as nonnative species threaten biodiversity and change ecosystem functioning [55]. Like in other parts of the Himachal Himalaya $[29,30]$ in SV also the percentage of native species increased with the altitude. There is a strong evidence from a scatter diagram that a positive linear relationship exists between the native species richness and altitude $(r=0.83, P<0.01, n=34)$ (Figure 3 ). The high percentage of the native species at higher elevations may be due to low anthropogenic pressure and severe climatic conditions compared to the lower elevations where high anthropogenic pressure and mild climatic conditions support the speciation of the nonnative species [30]. Regular monitoring of the habitats and populations of the native species facing high anthropogenic pressure even in higher altitude is essentially required, so that the adequate planning for their conservation and management could be done in time.

3.6. Altitudinal and Aspectwise Distribution of Species. Altitude and aspect are the most important determinants of vegetation distribution due to their direct impact on microclimate of the habitat $[56,57]$. The Himalayan region has typical topography and environment where biodiversity varies from aspect to aspect and habitats of the communities [58].

Maximum altitudinal distribution of few selected climate sensitive species, namely, Bistorta affinis, Fragaria nubicola, Geranium pratense, Pleurospermum candollei, Podophyllum hexandrum, Rhodiola heterodonta, Saussurea obvallata, Saxifraga sibrica, and Sedum ewersii, was studied in the valley. It was found to be highest in northeast followed by north, south, and southeast aspects (Figure 4). Species like Bistorta affinis reaching up to $4510 \mathrm{~m}$ and $3890 \mathrm{~m}$ in northeast and north aspects, respectively, are restricted to $3580 \mathrm{~m}$ and $3429 \mathrm{~m}$ in

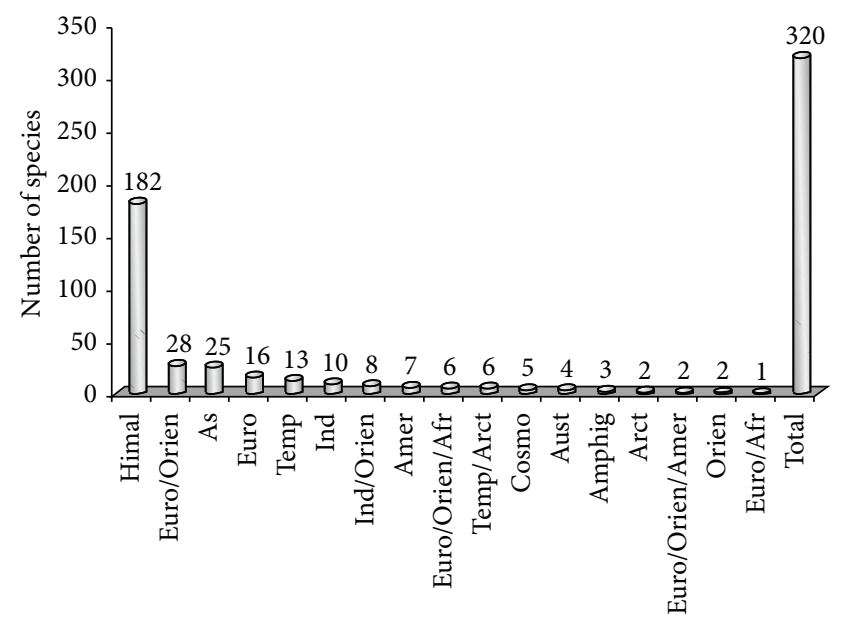

FIGURE 2: Species showing their biogeographic realms. Afr = Africa; Amer = America; Amphig = Amphigean; Arct = Arctic; As = Asia; Aust $=$ Australia; Cosmo $=$ Cosmopolitan; Euro $=$ Europe; Himal $=$ Himalaya; Ind = India; Orient $=$ Oriental; and Temp $=$ Temperate .

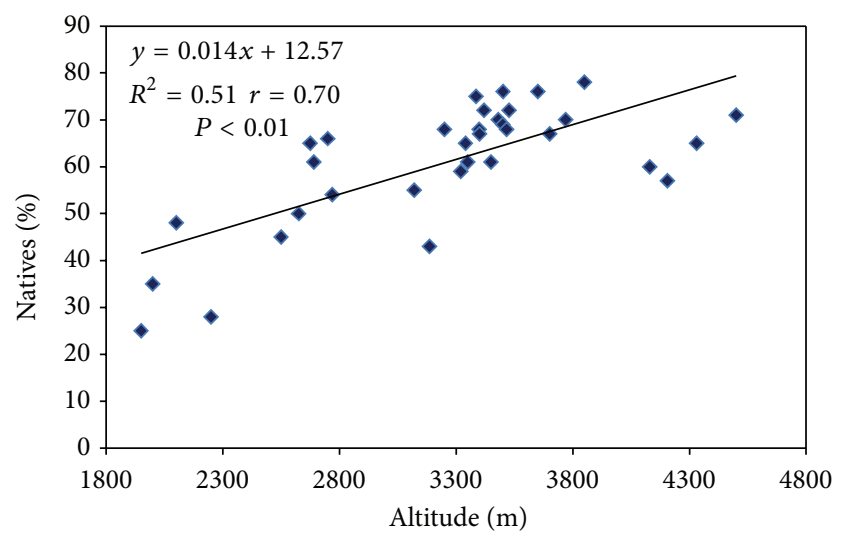

FIGURE 3: Native species along the altitude gradient.

south and southeast aspects, resepectively. Similar trend was seen with all other climate sesitive species in the region.

P. wallichiana showed the broadest range from 2100 to $3500 \mathrm{~m}$ and almost reaching the tree line along with B. utilis.

In this valley, northern and northeastern slopes have lower temperatures and higher soil and air moisture contents as compared to southern and other slopes at the same altitude due to less solar exposure and higher moisture content and evapotranspiration which is akin to the other Himalayan areas $[59,60]$. In northern and northeastern slopes B. utilis, A. pindrow, and $P$. wallichiana were recorded at the altitude as low as $2200 \mathrm{~m}$, whereas on the south and southeastern aspects their altitudinal range started from $2300 \mathrm{~m}$.

3.7. Final Considerations. In northwestern Himalaya the high mountain plant communities support a rich biodiversity in terms of ecological indicator species and natives. They need a proper management against harsh climate and anthropogenic 


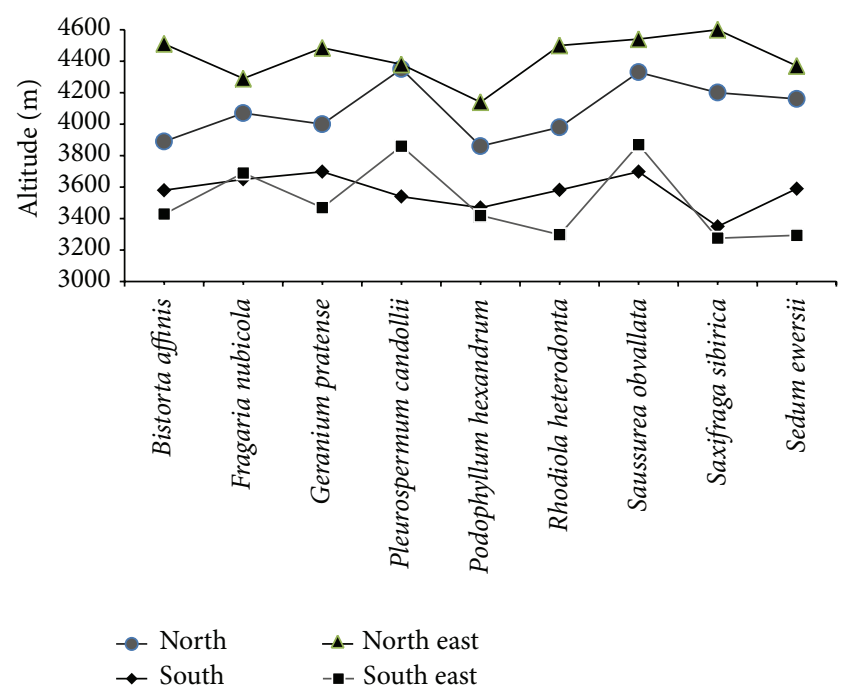

FIGURE 4: Distribution range of species along altitudinal gradient in different aspects.

pressure for continued future sustainability. Regular monitoring using random sampling by quadrat method is suggested to understand the dynamics of the habitats and communities and accordingly plan for their management. The climate sensitive species are required to be regularly monitored for their phenological attributes so that the baseline data can be generated for future changes in the area. The information generated on these lines will provide a better insight about the present status of floristic diversity and help in developing adequate strategies and action plan for the management of such biodiversity-rich areas. The state and central government agencies are suggested to encourage the native species so that the ambient regional ecosystems are protected for the posterity. Further, for in situ conservation of the economically and ecologically important species, regular monitoring of the sites and complete protection of the habitats is suggested. In addition, seed germination protocols developed may be used for mass multiplication of the species and seedlings should be transplanted in comparable habitats so that viable population of the species can be maintained. Finally a pragmatic and ameliorative conservational approach which was hitherto absent in this part of the Himalaya needs to be implemented.

\section{Conflict of Interests}

The authors declare that there is no conflict of interests regarding the publication of this paper.

\section{Acknowledgments}

Thanks are due to Department of Science and Technology, Government of India, for providing funds to conduct the study. The authors also thank and appreciate local communities for their cooperation and patience in providing the information and hospitality while undertaking surveys.

\section{References}

[1] C. P. Kala and V. B. Mathur, "Patterns of plant species distribution in the Trans-Himalayan region of Ladakh, India," Journal of Vegetation Science, vol. 13, no. 6, pp. 751-754, 2002.

[2] M. A. Oommen and K. Shanker, "Elevational species richness patterns emerge from multiple local mechanisms in Himalayan woody plants," Ecology, vol. 86, no. 11, pp. 3039-3047, 2005.

[3] J. S. Singh, "Sustainable development of the Indian Himalayan region: linking ecological and economic concerns," Current Science, vol. 90, no. 6, pp. 784-788, 2006.

[4] S. M. Khan, S. E. Page, H. Ahmad, and D. M. Harper, "Sustainable utilization and conservation of plant biodiversity in montane ecosystems: the Western Himalayas as a case study," Annals of Botany, vol. 112, no. 3, pp. 479-501, 2013.

[5] A. Chawla, S. Rajkumar, K. N. Singh, B. Lal, A. K. Thukral, and R. D. Singh, "Plant species diversity along an altitudinal gradient of Bhabha Valley in western Himalaya," Journal of Mountain Science, vol. 5, no. 2, pp. 157-177, 2008.

[6] H. Shaheen, Z. Ullah, S. M. Khan, and D. M. Harper, "Species composition and community structure of western Himalayan moist temperate forests in Kashmir," Forest Ecology and Management, vol. 278, pp. 138-145, 2012.

[7] S. Gairola, R. S. Rawal, and N. P. Todaria, "Forest vegetation patterns along an altitudinal gradient in sub-alpine zone of West Himalaya, India," African Journal of Plant Science, vol. 2, no. 6, pp. 42-48, 2008.

[8] N. Timilsina, M. S. Ross, and J. T. Heinen, "A community analysis of sal (Shorea robusta) forests in the western Terai of Nepal," Forest Ecology and Management, vol. 241, no. 1-3, pp. 223-234, 2007.

[9] IUCN, IUCN Red List of Threatened Species, IUCN, Glands, Switzerland, 2003.

[10] R. T. Busing, P. S. White, and M. D. Mackenzie, "Gradient analysis of old spruce-fir forest of the Great Smokey Mountains circa 1935," Canadian Journal of Botany, vol. 71, no. 7, pp. 951958, 1993.

[11] S. Pant and S. S. Samant, "Diversity and regeneration status of tree species in Khokhan Wildlife Sanctuary, North-Western Himalaya," Tropical Ecology, vol. 53, no. 3, pp. 317-331, 2012.

[12] O. Polunin and A. Stainton, Flowers of the Himalaya, Oxford University Press, Delhi, India, 1984.

[13] H. J. Chowdhery and B. M. Wadhwa, Flora of Himachal Pradesh, vol. 1-3, Botanical Survey of India, Calcutta, India, 1984.

[14] D. S. Dhaliwal and M. Sharma, Flora of Kullu District ( Himachal Pradesh), Bishen Singh Mahendra Pal Singh, Dehradun, India, 1999.

[15] S. K. Singh and G. S. Rawat, Flora of Great Himalayan National Park, Himachal Pradesh, Bishen Singh Mahendra Pal Singh, Dehradun, India, 2000.

[16] H. Singh and M. Sharma, Flora of Chamba District (Himachal Pradesh), Bishen Singh Mahinder Pal Singh, Dehradun, India, 2006.

[17] S. P. Khullar, An Illustrated Fern Flora of the West Himalaya Vol II, International Book Distributors, Dehradun, India, 2000.

[18] J. S. Singh and S. P. Singh, "Forest vegetation of the Himalaya," The Botanical Review, vol. 53, no. 1, pp. 80-192, 1987.

[19] M. S. Mani, "The Himalaya, its ecology and biogeography: a review," in High Altitudes of the Himalaya, Y. P. S. Pangtey and R. S. Rawal, Eds., Gyanodaya Prakashan, Nainital, India, 1994. 
[20] U. Dhar, R. S. Rawal, and S. S. Samant, "Structural diversity and representativeness of forest vegetation in a protected area of Kumaun Himalaya, India: implications for conservation," Biodiversity and Conservation, vol. 6, no. 8, pp. 1045-1062, 1997.

[21] B. P. Nautiyal, N. Pandey, and A. B. Bhatt, "Analysis of vegetation pattern in alpine zone in North West Himalaya: a case study of Garhwal Himalaya with special reference to diversity and distributional patterns," International Journal of Ecology and Environmental Sciences, vol. 23, no. 1, pp. 49-65, 1997.

[22] C. P. Kala, Ecology and conservation of alpine meadows in the Valley of Flowers National Park, Garhwal Himalaya [Ph.D. thesis], Forest Research Institute, Dehradun, India, 1998.

[23] J. S. Singh, "The biodiversity crisis: a multifaceted review," Current Science, vol. 82, no. 6, pp. 638-647, 2002.

[24] S. S. Samant and H. C. Joshi, "Floristic diversity, community patterns and changes of vegetation in Nanda Devi National Park," in Biodiversity Monitoring Expedition Nanda Devi 2003, pp. 39-54, Bishen Singh Mahendra Pal Singh, Dehradun, India, 2003.

[25] K. N. Singh, A. Kumar, B. Lal, and N. P. Todaria, "Species diversity and population status of threatened plants in different landscape elements of the Rohtang Pass, western Himalaya," Journal of Mountain Science, vol. 5, no. 1, pp. 73-83, 2008.

[26] M. Adnan and D. Hölscher, "Medicinal plants in old-growth, degraded and re-growth forests of NW Pakistan," Forest Ecology and Management, vol. 261, no. 11, pp. 2105-2114, 2011.

[27] M. Adnan and D. Hölscher, "Diversity of medicinal plants among different forest-use types of the Pakistani Himalaya," Economic Botany, vol. 66, no. 4, pp. 344-356, 2012.

[28] H. C. Joshi and S. S. Samant, "Assessment of forest vegetation and conservation priorities of communities in part of Nanda Devi Biosphere Reserve, West Himalaya: part I," International Journal of Sustainable Development and World Ecology, vol. 11, no. 3, pp. 326-336, 2004.

[29] M. Lal, Assessment of floristic diversity and conservation status of plants in kais wildlife sanctuary of himachal pradesh in Northwestern Himalaya [Ph.D Thesis], Kumaun University, Nainital, India, 2007.

[30] M. S. Rana, Assessment of floristic diversity and conservation prioritization of communities for conservation in Manali Wildife Sanctuary of Himachal Pradesh in Northwestern Himalaya [Ph.D. thesis], Kumaun University, Nainital, India, 2007.

[31] A. Sharma, Studies on Floristic diversity and prioritization of communities for conservation in Hirb and Shoja Catchments, District Kullu of Himachal Pradesh, North Western Himalaya [Ph.D. thesis], Kumaun University, Nainital, India, 2008.

[32] W. A. Rodgers and H. S. Panwar, A Biogeographical Classification for Conservation Planning, Wildlife Institute of India, Dehradun, India, 1990.

[33] E. C. Pielou, Ecological Diversity, John Wiley \& Sons, New York, NY, USA, 1975.

[34] E. H. Simpson, "Measurement of diversity," Nature, vol. 163, article 688, 1949.

[35] C. E. Shannon and W. Wiener, The Mathematical Theory of Communication, University of Illinois Press, Urbana, Ill, USA, 1963.

[36] J. T. Curtis and M. Intosh, "The interrelation of certain analytic and phytosociological characters," Ecology, vol. 31, pp. 434-455, 1950.

[37] P. Greig-Smith, Quantitative Plant Ecology, Academic Press, New York, NY, USA, 1957.
[38] K. A. Kersaw, Quantitative and Dynamic Plant Ecology, Edward Arnold Limited, London, UK, 2nd edition, 1973.

[39] D. Muller-Dombois and H. Ellenberge, Aims and Methods of Vegetation Ecology, John Willey and Sons, New York, NY, USA, 1974.

[40] A. K. Saxena and J. S. Singh, "A phytosociological analysis of woody species in forest communities of a part of Kumaun Himalaya," Vegetatio, vol. 50, no. 1, pp. 3-22, 1982.

[41] A. E. Osmaston, A Forest Flora for Kumaun, International Book Distributors, Dehradun, India, 1927.

[42] B. S. Aswal and B. N. Mehrotra, Flora of Lahaul-Spiti (A Cold Desert in North-West Himalaya), Bishen Singh Mahendra Pal Singh, Dehradun, India, 1994.

[43] S. S. Samant, H. C. Joshi, and S. C. Arya, "Diversity, nativity and endemism of vascular plants in Pindari area of Nanda Devi Biosphere Reserve-II," Himalayan Biosphere Reserves, vol. 2, no. 1-2, pp. 1-29, 2000.

[44] O. P. Chaturvedi and J. S. Singh, "The structure and function of pine forest in central himalaya. I: dry matter dynamics," Annals of Botany, vol. 60, no. 3, pp. 237-252, 1986.

[45] C. Bindiu, Unpublished Ph.D. thesis, Acadamic de stunte agricole si silvice [Ph.D. thesis], Acadamic de stunte agricole si silvice, Bucharest Romania, 1973.

[46] G. P. Raturi, "Forest community structure along an altitudinal gradient of district Rudraprayag of Garhwal Himalaya, India," Ecologia, vol. 2, no. 3, pp. 76-84, 2012.

[47] B. S. Adhikari, H. C. Rikhari, Y. S. Rawat, and S. P. Singh, "High altitude forest: composition diversity and profile structure in a part of Kumaun Himalaya," Tropical Ecology, vol. 32, no. 1, pp. 86-97, 1991.

[48] N. S. Bankoti, R. S. Rawal, S. S. Samant, and Y. P. S. Pangtey, "Forest vegetation of inner hill ranges in kumaun, central himalaya," Tropical Ecology, vol. 33, no. 1, pp. 41-53, 1992.

[49] H. C. Joshi, Assessment of habitat diversity, forest vegetation and human dependence in the Buffer zone of Nanda Devi biosphere reserve of West Himalaya [Ph.D. thesis], Kumaon University, Nainital, India, 2002.

[50] J. C. Tewari and S. P. Singh, "Vegetational analysis of a forest lying in transitional zone between lower and upper Himalayan moist temperate forests," in The vegetational wealth of Himalaya, S. G. Paliwal, Ed., Puja Publishers, New Delhi, India, 1981.

[51] S. S. Samant, H. C. Joshi, S. C. Arya, and S. Pant, "Studies on the structure, composition and changes of vegetation in Nanda Devi Biosphere Reserve of west Himalaya," Tech. Rep., Ministry of Environment and Forests, New Delhi, India, 2002.

[52] M. Ahmed, T. Husain, A. H. Sheikh, S. S. Hussain, and M. F. Siddiqui, "Phytosociology and structure of Himalayan forests from different climatic zones of Pakistan," Pakistan Journal of Botany, vol. 38, no. 2, pp. 361-383, 2006.

[53] R. M. Kunwar and S. P. Sharma, "Quantitative analysis of tree species in two community forests of Dolpa district, mid-west Nepal," Himalayan Journal of Science, vol. 2, no. 3, pp. 23-28, 2004.

[54] S. Shah, A. Tewari, and B. Tewari, "Impact of Human disturbance on forest vegetation and water resources of nainital catchment," Natural Science, 2009.

[55] J. M. Levine, M. Vilà, C. M. D’Antonio, J. S. Dukes, K. Grigulis, and S. Lavorel, "Mechanisms underlying the impacts of exotic plant invasions," Proceedings of the Royal Society B: Biological Sciences, vol. 270, no. 1517, pp. 775-781, 2003. 
[56] R. S. Rawal and Y. P. S. Pangtey, "Distribution and structuralfunctional attributes of trees in the high altitude zone of Central Himalaya, India,” Vegetatio, vol. 112, no. 1, pp. 29-34, 1994.

[57] H. Singh, M. Kumar, and A. M. Sheikh, "Distribution pattern of Oak and Pine along altitudinal gradients in Garhwal Himalaya," Natural Science, vol. 7, no. 11, pp. 81-85, 2009.

[58] R. E. Shank and E. N. Noorie, "Microclimate vegetation in a small valley in eastern Tennessee," Ecology, vol. 11, p. 5319, 1950.

[59] C. M. Sharma and N. P. Baduni, "Effect of aspect on the structure of some natural stands of Abies pindrow in Himalayan moist temperate forest," Environmentalist, vol. 20, no. 4, pp. 309-317, 2000.

[60] M. P. Panthi, R. P. Chaudhary, and O. R. Vetaas, "Plant species richness and composition in a trans-Himalayan inner valley of Manang District, Central Nepal," Himalayan Journal of Sciences, vol. 4, no. 6, pp. 27-39, 2007. 

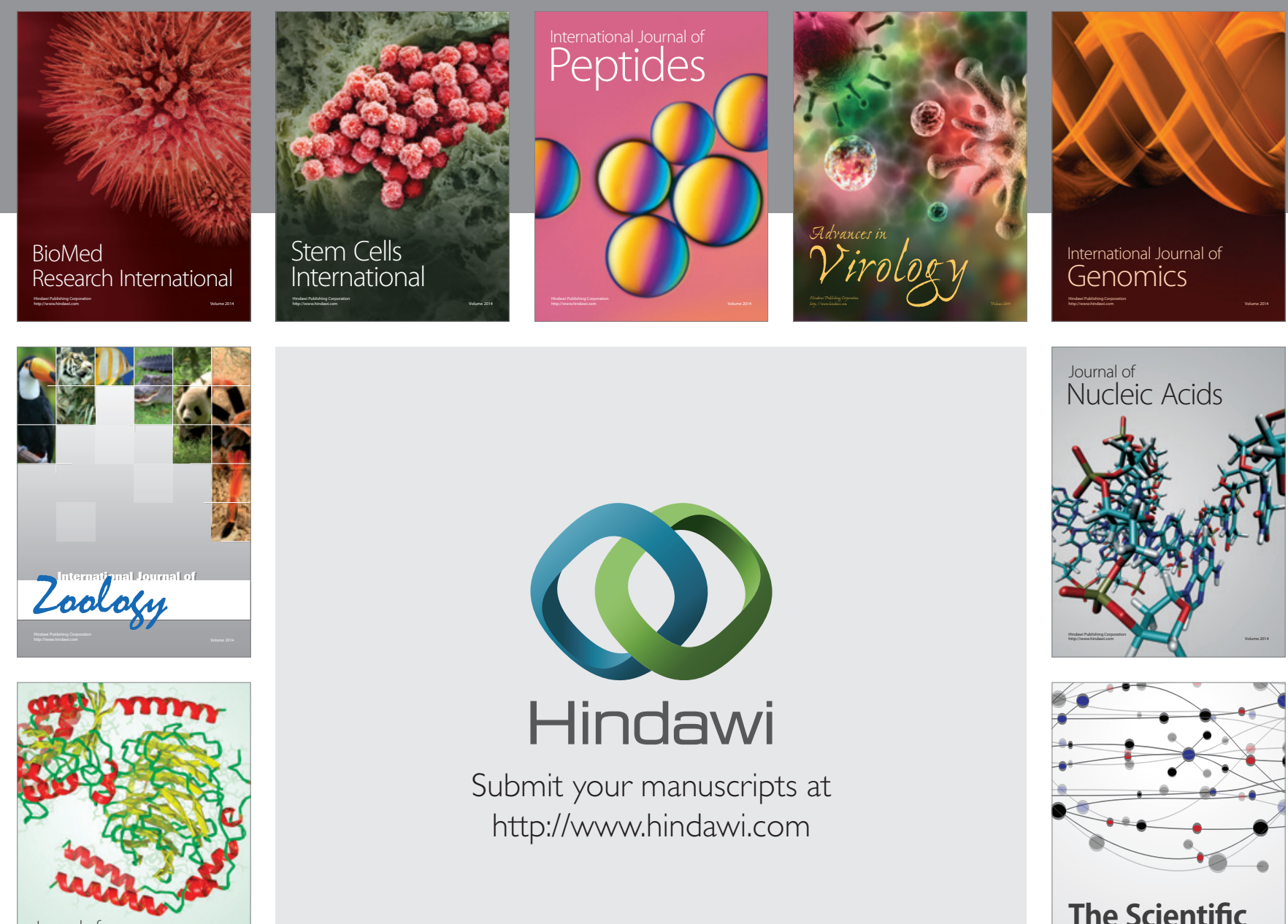

Submit your manuscripts at

http://www.hindawi.com

Journal of
Signal Transduction
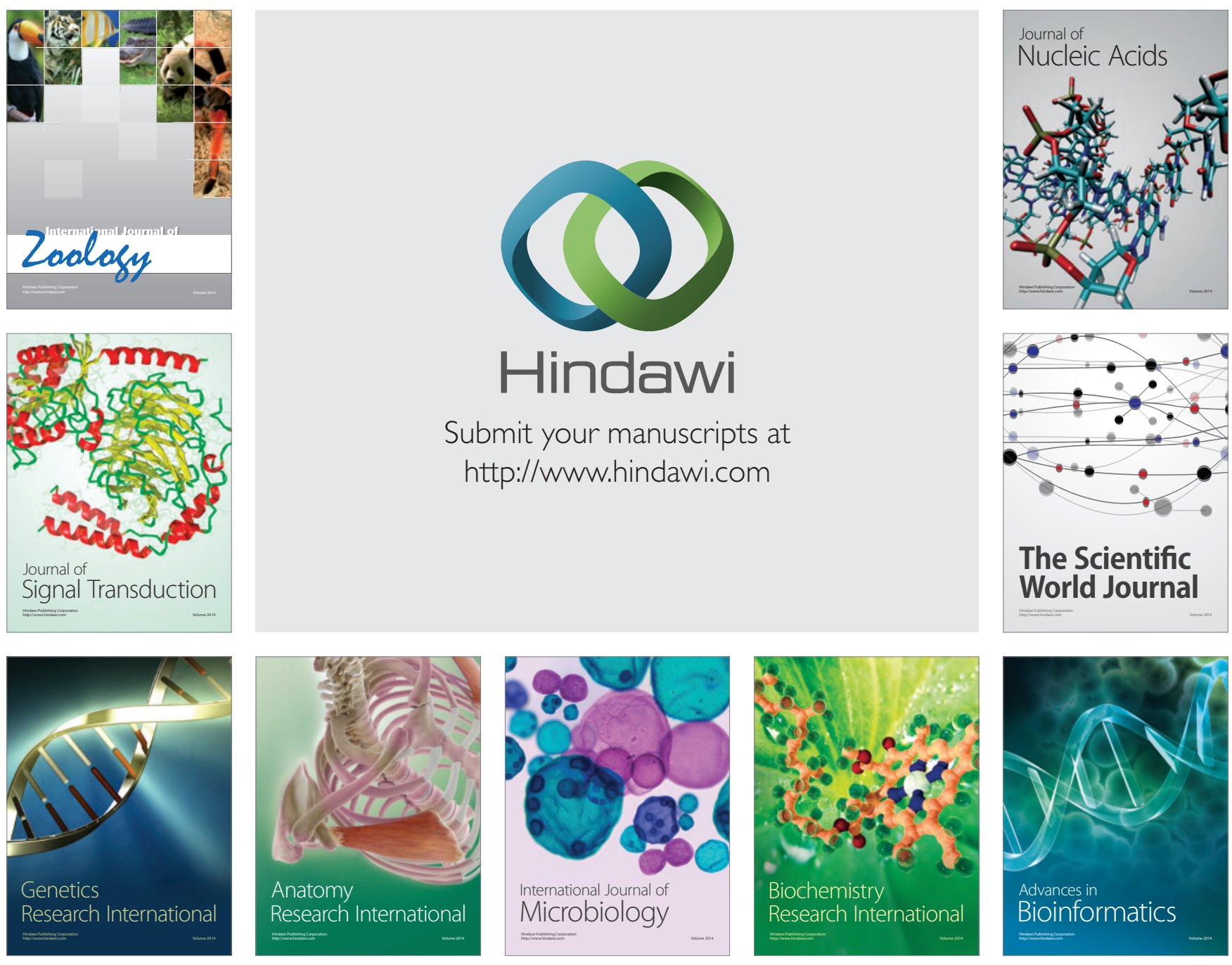

The Scientific World Journal
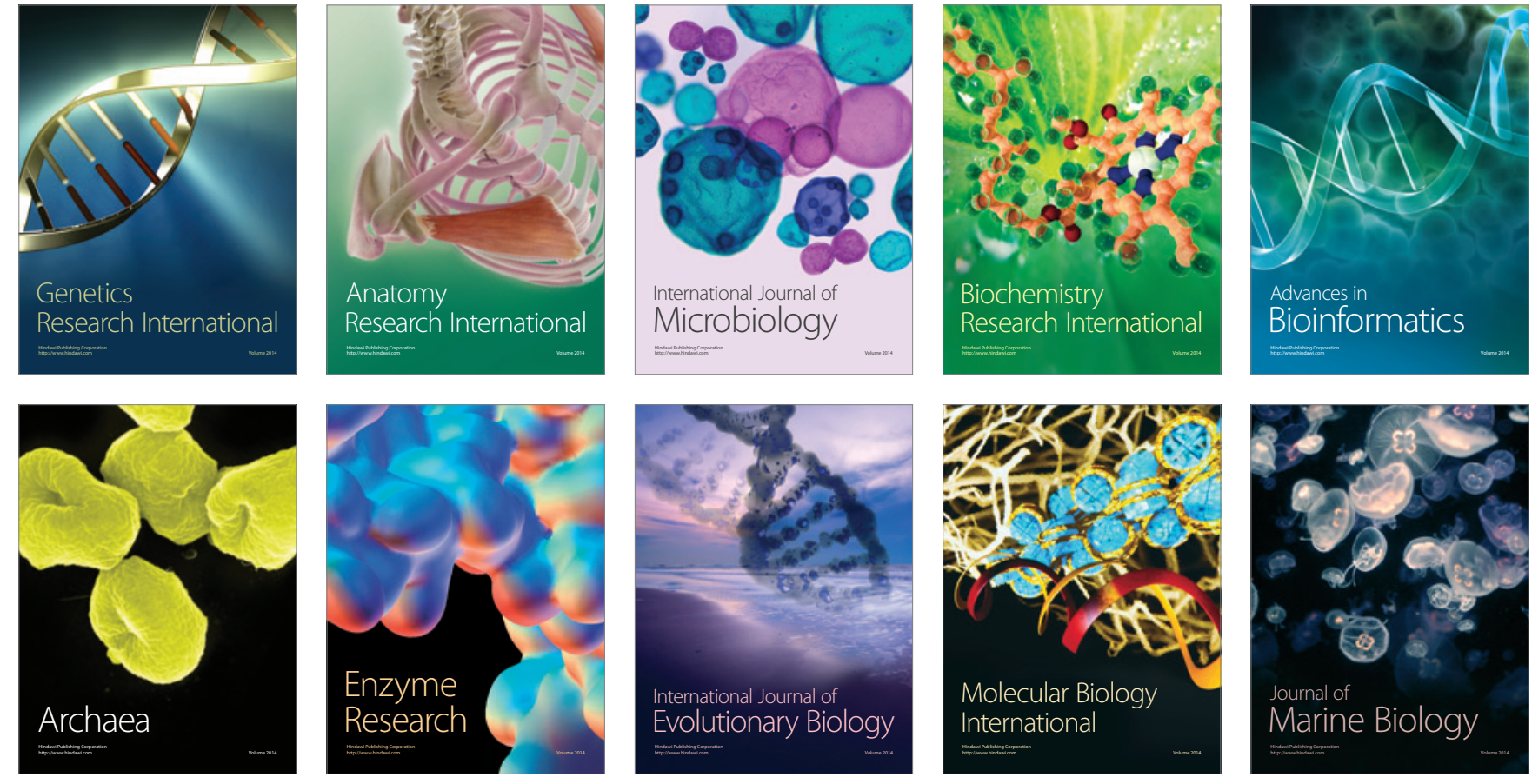